\title{
Forest Cover Monitoring and Change Detection in Nfifikh Forest (Morocco)
}

\author{
Loubna Khalile*, Hassan Rhinane, Abdelhadi Kaoukaya, Hicham Lahlaoi \\ Faculté des Sciences Aïn Chock, Université Hassan II-Casablanca, Casablanca, Morocco \\ Email: *loubna.khalile@etude.univcasa.ma
}

How to cite this paper: Khalile, L., Rhinane, H., Kaoukaya, A. and Lahlaoi, $\mathrm{H}$. (2018) Forest Cover Monitoring and Change Detection in Nfifikh Forest (Morocco). Journal of Geographic Information System, 10, 219-233.

https://doi.org/10.4236/jgis.2018.102011

Received: December 27, 2017

Accepted: April 8, 2018

Published: April 11, 2018

Copyright $\odot 2018$ by authors and Scientific Research Publishing Inc. This work is licensed under the Creative Commons Attribution International License (CC BY 4.0).

http://creativecommons.org/licenses/by/4.0/

\begin{abstract}
Peri-urban forests are subject to different dynamics due to several factors. Nfifikh forest is a man-made space, located in suburban of Mohammedia City, belonging to Casablanca, Settat Region, and geographically between Casablanca, the economic and business Capital of Morocco and Rabat, the national political capital. Over the past three decades, it has experienced several significant degradations. The aim of this study is to evaluate and quantify the deforestation within the study area using a forest cover change detection of various vegetation indices and subpixel classification to pick out high density plots with Landsat images TM, $\mathrm{ETM}^{+}$and OLI. Remote sensing is used to highlight the changes caused through Space-Time. This monitoring might help managers to generate forest management plans and to moderate the speed of deforestation and degradation. The results show a significant change in vegetation cover detected between 1987 and 2015. The Density increased in 2001 while it decreased considerably in 2015.
\end{abstract}

\section{Keywords}

Subpixel, Vegetation Indices, Change Detection, Monitoring, Nfifikh Forest

\section{Introduction}

According to the first Forest Inventory in Morocco conducted between 1990 and 2005 , forests cover an area of about 9 million hectares, or $12.7 \%$ of the national territory [1]. Moroccan poorly managed forest biodiversity is degrading because of the loss of natural resources. These green spaces are over frequented by eco-tourists who damage the landscape with waste that sometimes causes wildfires [2]. The forest is furthermore damaged by resident workers who are responsible for forest over-grazing as well as illegal logging [3].

The use of remote sensing and GIS in forestry is a major asset with high spa- 
tial resolution satellite data [4] [5] [6]. Several studies have been conducted about forest degradation and cover change detection [7] [8] [9] [10]. At Sumatra Island in Indonesia, mapping and monitoring deforestation and forest degradation were realized by Margono et al. [11]. Moreover, vegetation indices are very useful to evaluate the performance of the spatial coverage [12] [13] [14] [15]. Some of these studies were based on Normalized Difference Vegetation Index differencing Change Detection [16] [17], Soil-Adjusted Vegetation Index [18], Tasseled Cap [15] and Subpixel classification [19].

According to Ghebrezgabher et al. [20], the normalized difference vegetation index is the most used factor in vegetation studies. Kumar et al. [21] has used NDVI to monitor deforestation and forest degradation in India. NDVI gives an overview of the quality and density of vegetation [22]. Nori et al. [23] integrated NDVI and SAVI to evaluate the potential for monitoring forest change in Sudan. The soil-adjusted vegetation index is a modification of the normalized difference vegetation index in order to correct the influence of the soil brightness [24]. In some studies, Forest disturbances can be detected using Tasseled cap [25] [26] [27] [28]. Healey et al. [25] used tasseled cap for the detection of forest disturbances in the Unites States and Russia. Tasseled Cap Greenness, Wetness and Brightness are the three plans of the Tasseled cap index that give optimized results of soil moisture and vegetation [29] [30] [31]. Huguenin et al. [32] detected in mixed pixels using the subpixel classification, cypress and tupelo trees in humid areas in Georgia and South Carolina in the United States. Subpixel Classification has stronger capabilities compared to alternative per pixel methods [33]. In literature, there are numerous techniques to calculate change detection: image differencing [34] [35], vegetation index differencing [36] [37], and others advanced methods [38] [39] [40] [41] [42] are developed to meet the real need for complex forest changes.

The objectives of this study are the detection of forest cover changes, using Landsat images acquired during different years, and the quantification of the degradation without taking into consideration climatic influences. Compared to other approaches over regional or national areas, this study collects several results by integrating subpixel to vegetation indices.

\section{Materials and Methods}

\subsection{Study Area}

The Nfifikh forest is a man-made area of 533 ha, close to the town of Mohammedia, It belongs of the province of Benslimane and the prefecture of Mohammedia, Chaouia Ourdigha, the Region of Casa-Settat [43] [44].

It attended by Casablanca, Mohammedia and Benslimane inhabitants. It is visited by about 2000 people daily from February to April every year [43], according to the High Commission for Water and Forests. After a field visit, the forest has experienced a significant deterioration.

This forest was planted between 1921 and 1936 by a ministerial decree of June 
$20^{\text {th }}, 1921[43]$.

The Forest is limited by the Lambert coordinates of North Morocco system as follows: North: \{x: 321,000 y: 348,000\}; South: \{x: 321,000 y: 344,600\}; East: $\{x$ : $322,000 \mathrm{y:} 346,500\}$ and West: $\{\mathrm{x}: 320,000 \mathrm{y:} 346,700\}$ (Figure 1).

The forest is characterized by:

1) Relief: Majority of flat land with a great diversity of landscapes, the altitude can reach one hundred meters in some places with the most dominant altitudinal classes of 25 - $40 \mathrm{~m}$ and those of $40-60 \mathrm{~m}$ altitude. There is a presence of slope ranging from 0 to more than $45 \%$. Nfifikh forest is dominated by generally flat terrain with some uneven topography.

2) Geology/Soil science: Presence of schists and quartzite of primary age with conglomerates and calcareous Pliocene-Quaternary.

3) Climate: Semi-arid to temperate and hot variant

4) Flora: Eucalyptus camaldulensis, Eucalyptus gomphocephala, Pinus halepensis, Quercus suber (cork oak) with Thuja and Acacia on highly restricted ranges and a variety of shrubs [45].

5) Fauna: Wild boar is plentiful with hare, rabbit, partridge and common wood pigeon (Columba palumbus).

6) Hydrology: The hydrographic system of Oued Nfifikh belongs to the watershed Atlantic coastal rivers and Chaouia, he feeds the water area and has low flows throughout the wet period and high flow rates during the period of floods.

\subsection{Data Collection}

Landsat satellite images were used during the period 1987 and 2015, downloaded
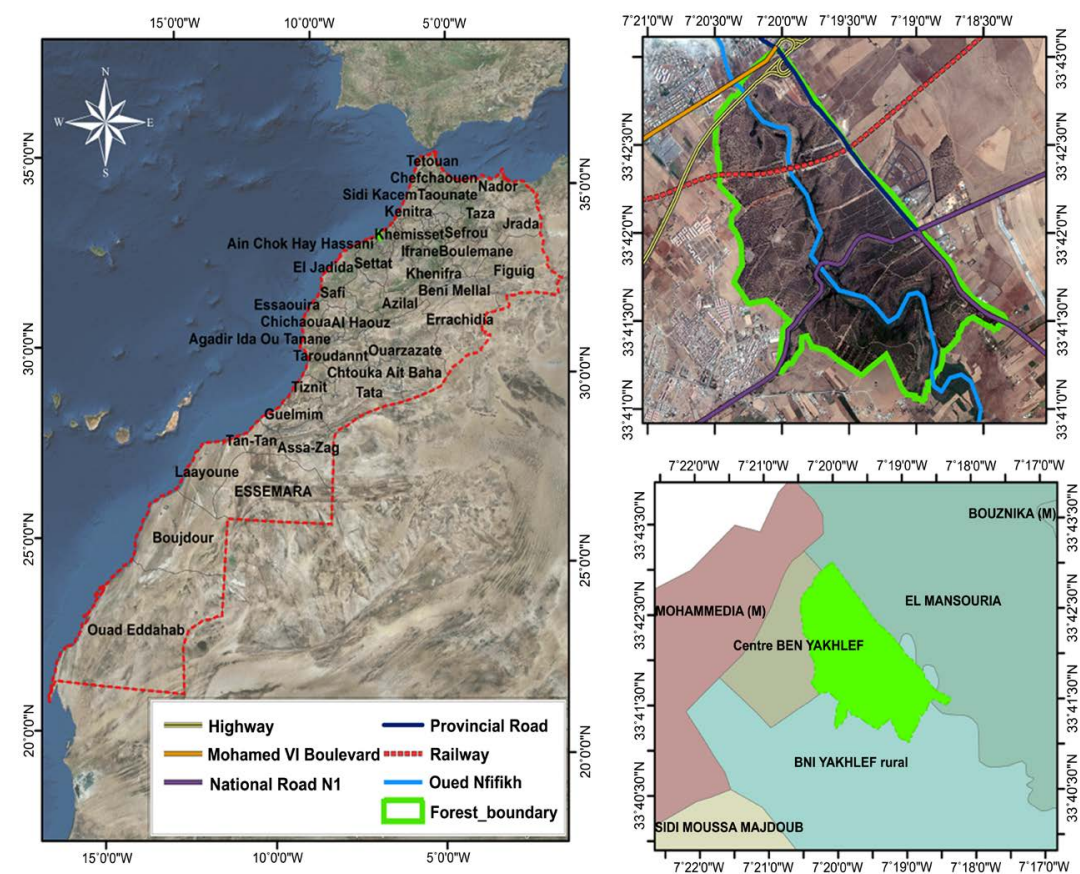

Figure 1. Geographical location of Nfifikh forest (Source: World Imagery Map and New Moroccan territorial division Map). 
from the US Geological National Center (USGC). Landsat 5 Thematic Mapper (TM) acquired on January $6^{\text {th }}, 1987$, Landsat 7 Enhanced Thematic Mapper Plus $\left(\mathrm{ETM}^{+}\right)$on January, $20^{\text {th }}, 2001$ and Landsat 8 Operational Land Imager (OLI) on January $3^{\text {rd }}, 2015$.

The satellite images are georeferenced and orthorectified with $30 \mathrm{~m}$ Spatial Resolution in the UTM (zone 29N, datum WGS 84) [46].

The ground truth was obtained by a field visit and Topographic map of Mohammedia 1:50,000 (NI-29-XI-4ac) and Map of Stand types 1:20,000 from Water and Forests Direction of Casablanca Center.

\subsection{Methodological Gait}

\subsubsection{Vegetation Indices}

There is a multitude of vegetation indices in the literature used in various fields [34] [47] [48]. This study uses three of the most common indices treating different ecological applications and forest research.

1) The normalized difference vegetation index (NDVI) (1) is used to generate relative biomass, it measures the relationship between spectral response and vegetation cover [49]. According to Zhang et al. [50] NDVI is a reliable marker for estimating ecosystem variation, they used it to assessed the temporal and spatial changes in alpine grassland in Northern Tibet, also Aguilar et al. [51] calculated NDVI to evaluate changes in the summer growing season in woody communities on Hog Island in the United States.

2) The Soil-Adjusted Vegetation Index (SAVI) (2), shows underneath soil conditions and aims to attenuate its effects on the vegetation, using a constant soil adjustment factor " $L$ " [52]. This factor varies with soil reflectivity and depends on density and vegetation, usually $L=0.5$.

3) The Tasseled cap is designed to analyze and map any changes related to vegetation, urbanization, soil, or other developments [53]. The output file offers three information plans which focus solely on two levels in our study: Greenness (3) and Wetness (4). The algorithm for these levels of information is the weighted sum of the bands multiplied by their respective coefficients of the Landsat images.

$$
\begin{gathered}
\text { NDVI }=(\mathrm{NIR}-\mathrm{Red}) /(\mathrm{NIR}+\mathrm{Red}) \\
\text { SAVI }=[(\mathrm{NIR}-\mathrm{Red}) /(\mathrm{NIR}+\mathrm{Red}+L)] *(1+L) \\
\text { Greenness }=-0.2848(\text { Blue })-0.2435(\text { Green })-0.5436(\text { Red }) \\
+0.7243(\mathrm{NIR})+0.0840(\text { SWIR I })-0.1800(\text { SWIR II }) \\
\text { Wetness }=0.1509(\text { Blue })+0.1973(\text { Green })+0.3279(\text { Red }) \\
+0.3406(\text { NIR })-0.7112(\text { SWIR I })-0.4572(\text { SWIR II })
\end{gathered}
$$

\subsubsection{Subpixel Classification}

Subpixel Classification was used to detect and identify within a pixel the materials of interest from others [32] where the pixel acquires various labels. The subpixel classification exploits the spectral information of the image. It improves 
the classification by identifying different classes in the single pixel spectrum [54]. It was applied using "ERDAS Imagine 2014", the material of interest (MOI) chosen is dense plots.

More than 20 samples were taken from the satellite images in the study area as training samples to generate a single signature of the dense plots. This signature is used in the classification process to identify all pixels in the study area with similar spectral properties to the training samples [55].

\subsubsection{Change Detection and Weighted Overlay Analysis}

Change detection evaluates and identifies any difference changes between two images in the same study area at different dates [56]. In this study Image differencing is used by subtracting the recent image from the old one to know the extent of the change [57]. The change detection [7] was calculated using the first and last outputs of the indices and classification. The results were combined with the Weighted Overlay [58] [59] all Change detection indices and classification [60]. Each factor was classified into three classes: increase, decrease and unchanged; and was applied at the same percentage influence. The deforestation susceptibility map is obtained by overlaying all maps in terms of weighted overlay methods using the spatial analysis tool in ArcGIS 10.4 [61].

\section{Results and Discussions}

The resulting maps of the vegetation indices show a considerable variable of forest density. Figure 2 shows the representation of the NDVI minimum value recorded was -0.45 in 1987, SAVI and Wetness which is respectively: -0.67 and -0.46 , whereas for the greenness, the minimum value of -0.38 is recorded in 2001. The maximum value recorded is in 2001 for the four indices: NDVI $=$ 0.743 ; $\mathrm{SAVI}=1.11$; Greenness $=0.76$ and Wetness $=0.502$.

Green areas in NDVI represent vegetation, and the SAVI and Tasseled Cap show fairly similar results.

Between 1987 and 2001, the density of the vegetation increases according to the indices, however, there is a remarkable decrease between 2001 and 2015. The dense plots extracted by subpixel classification decreased slightly between 1987, 2001 and 2015.

The NDVI has regressed significantly between 1987 and 2015 with an area of 449.01 hectares. The other indices confirm the regression, for SAVI there is a degradation of 442.8 hectares, and for TC Greenness and Wetness we have respectively 322.2 hectares and 415.53 hectares (Table 1 ).

For the subpixel classification Pixels representing dense areas in forest and were designated as the MOI (Figure 3 ) by identifying areas with high vegetation indices values. Subpixel classification produces four classes. Each one indicates the percentage of MOI in each pixel. The fourth class is the most interesting in this study, where the MOI is present between $80 \%$ to $100 \%$, it represents $41.80 \%$ of the total forest area in 1987, 40.66\% in 2001 and only $38.36 \%$ in 2015 . There is a significant reduction of forest biomass. For accuracy assessment, the overall 


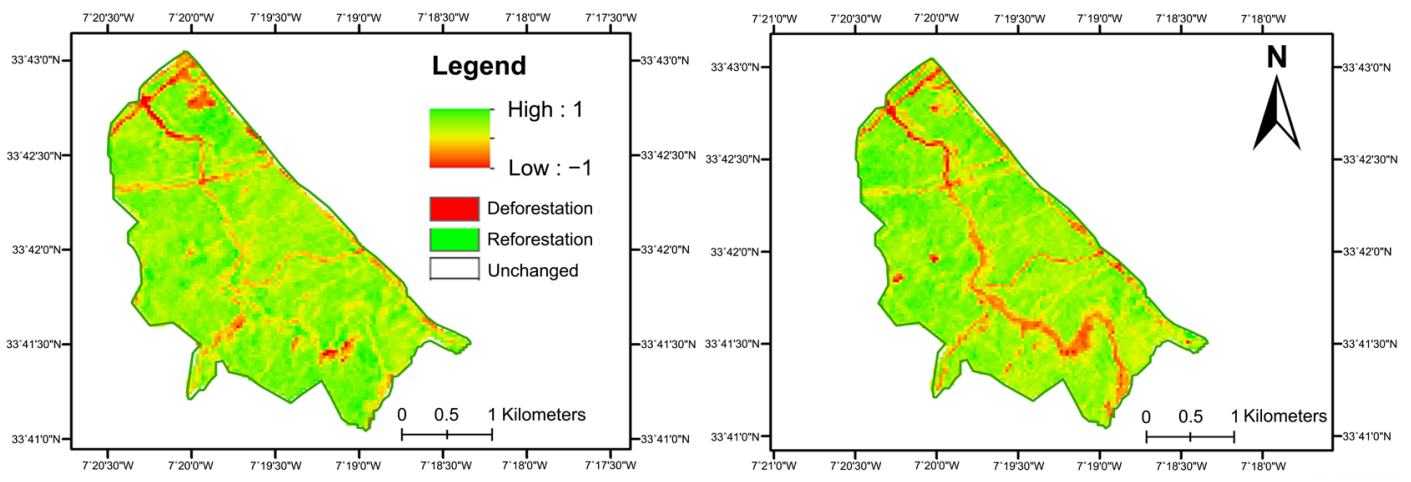

(a)

(b)

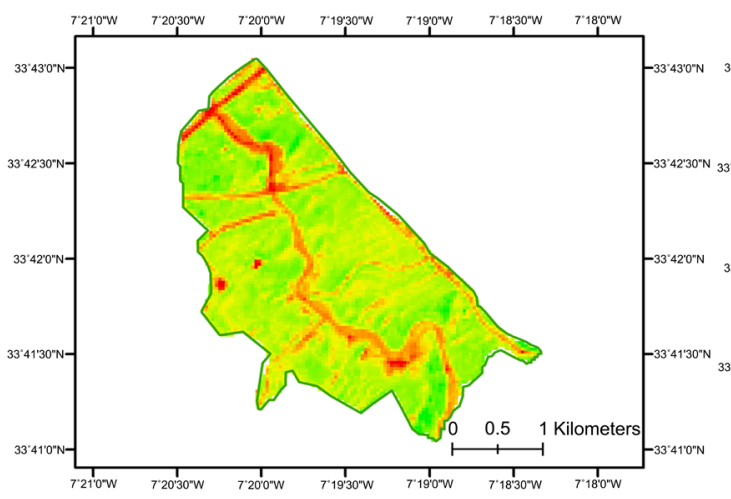

(c)

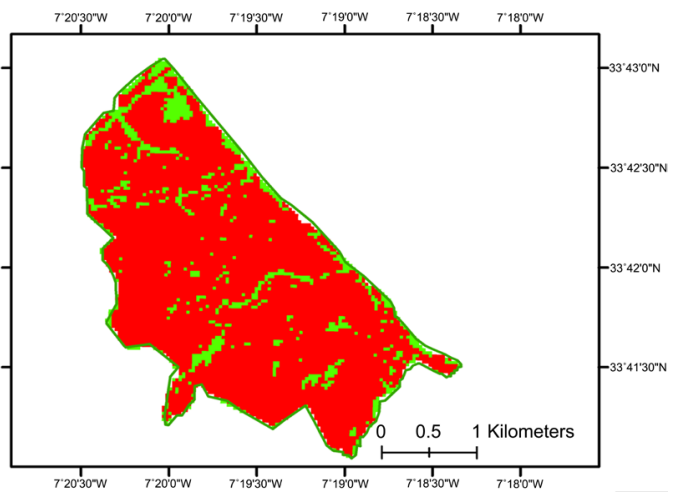

(d)

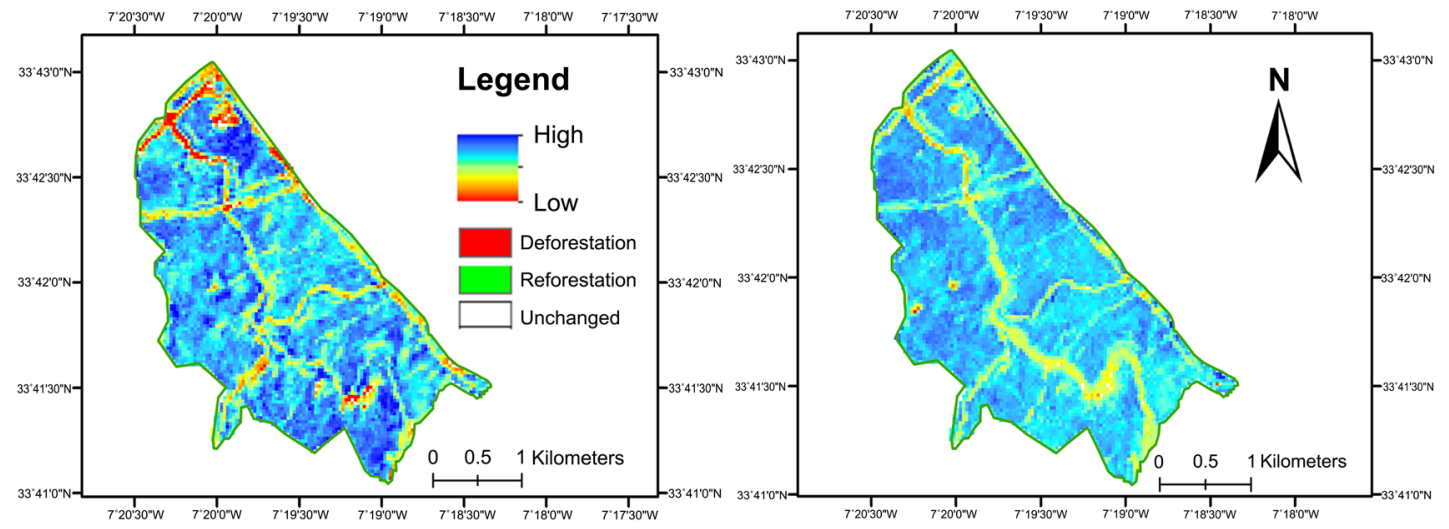

(e)

(f)

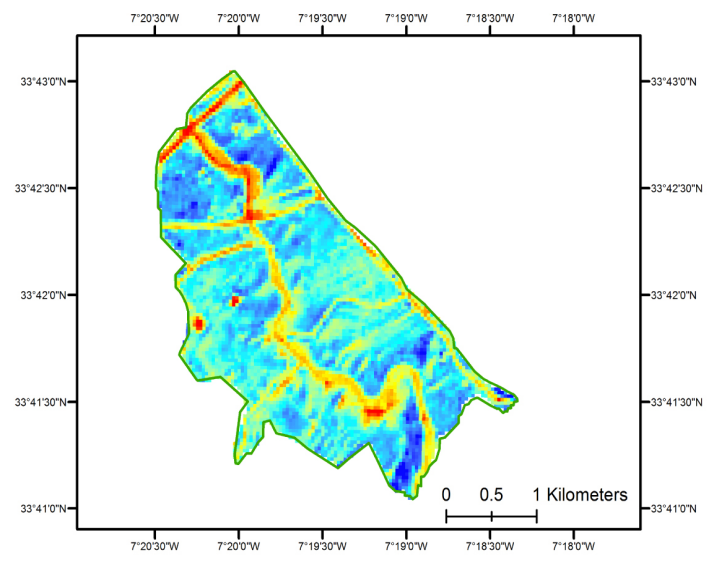

(g)

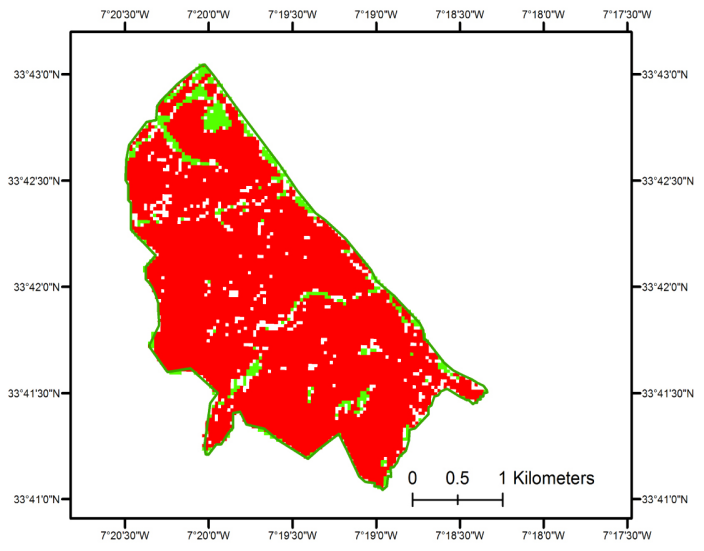

(h) 


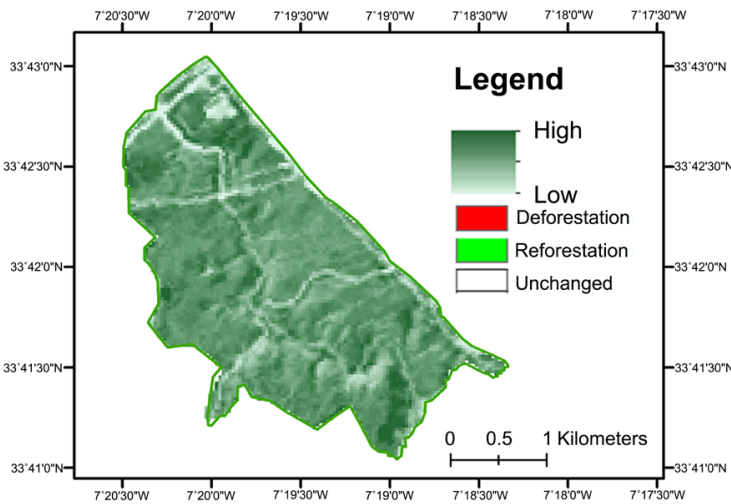

(i)

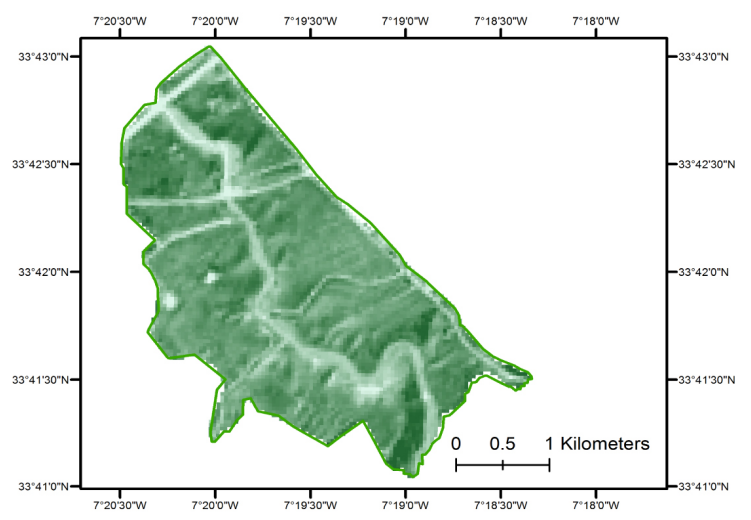

(k)

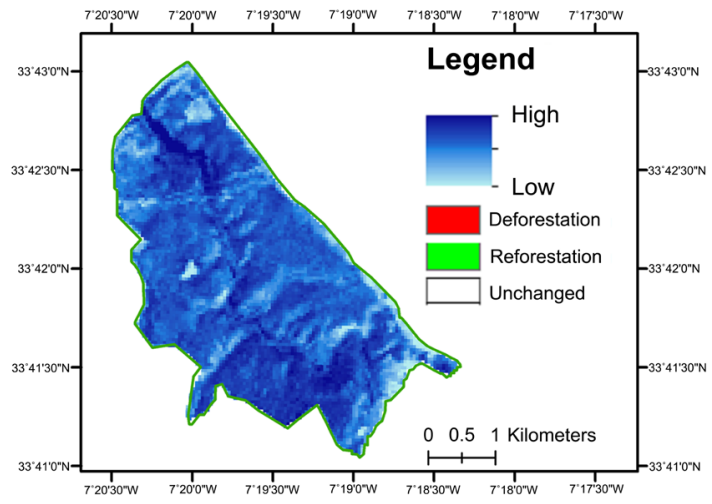

(m)

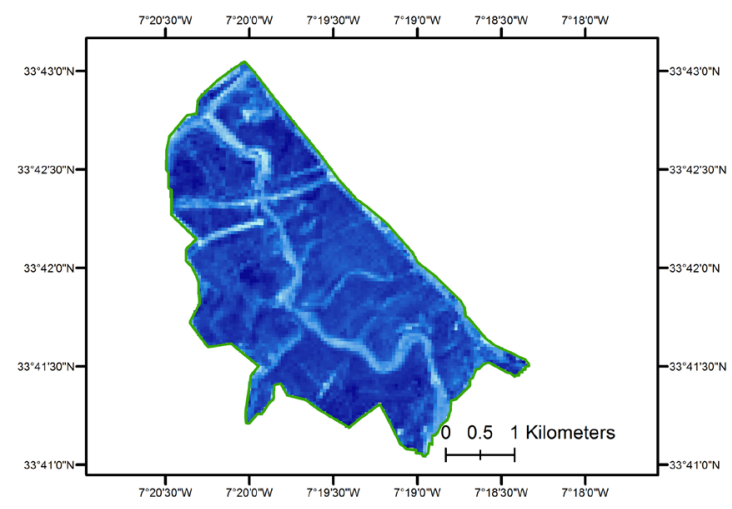

(o)

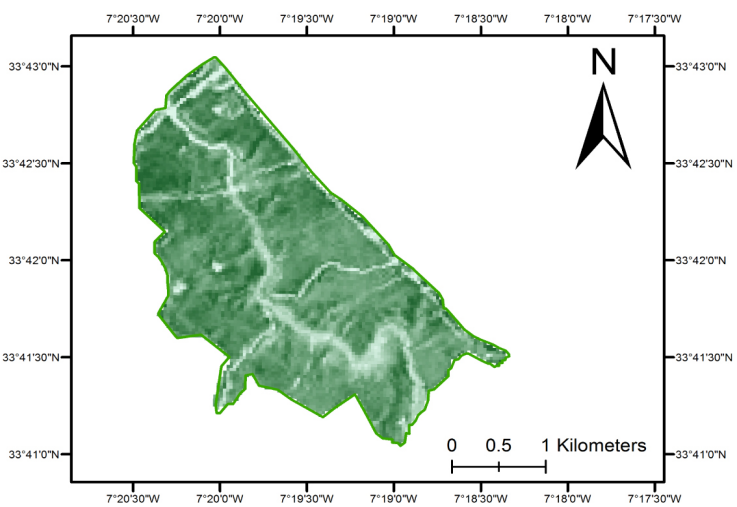

(j)

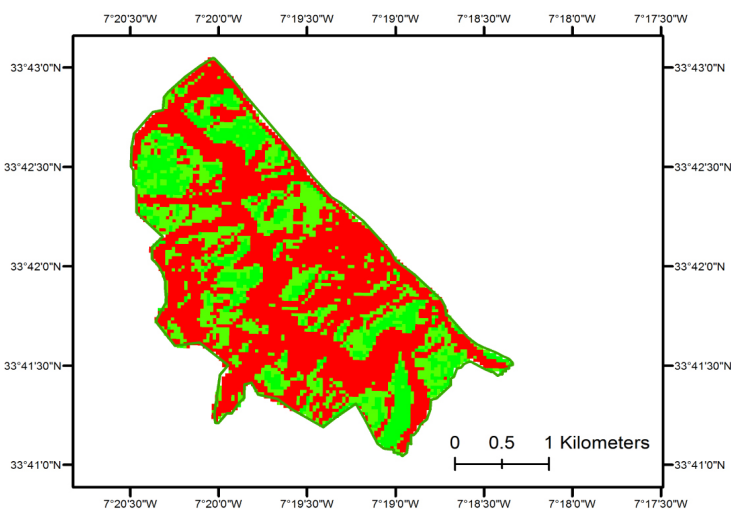

(l)

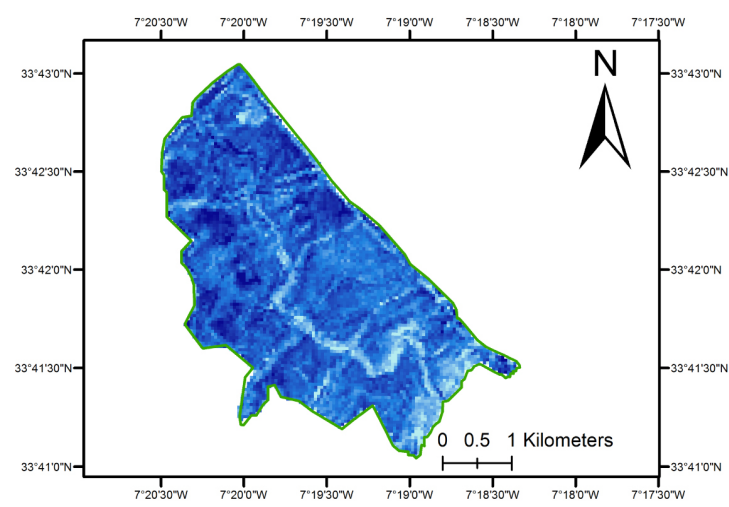

(n)

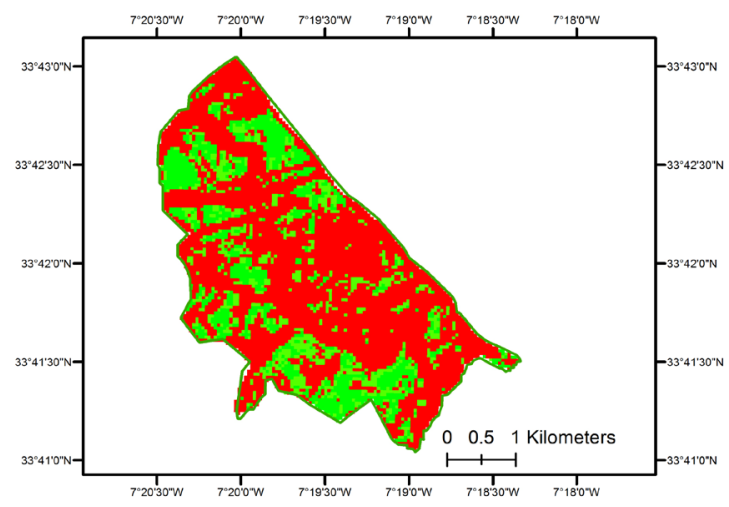

(p) 


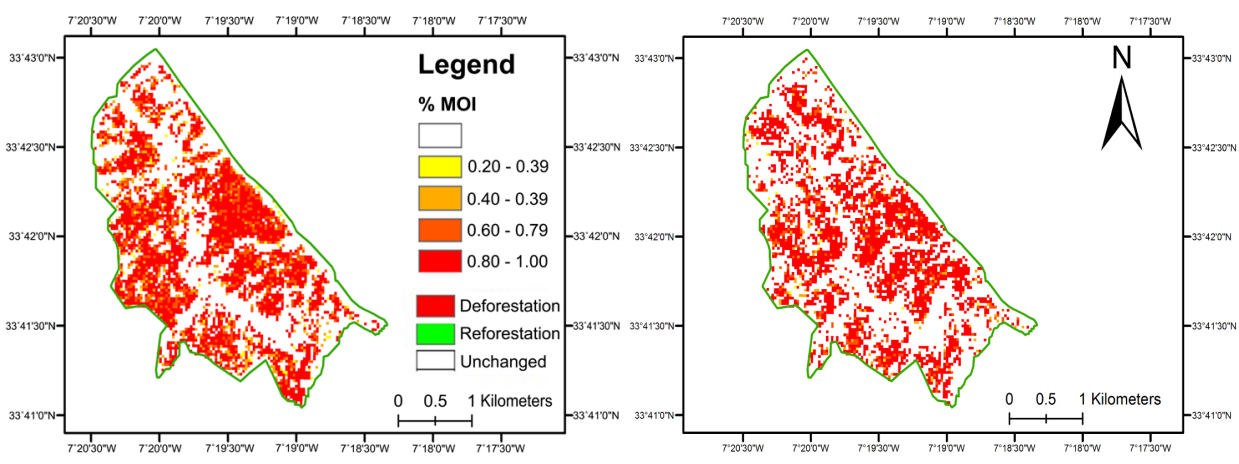

(q)

(r)

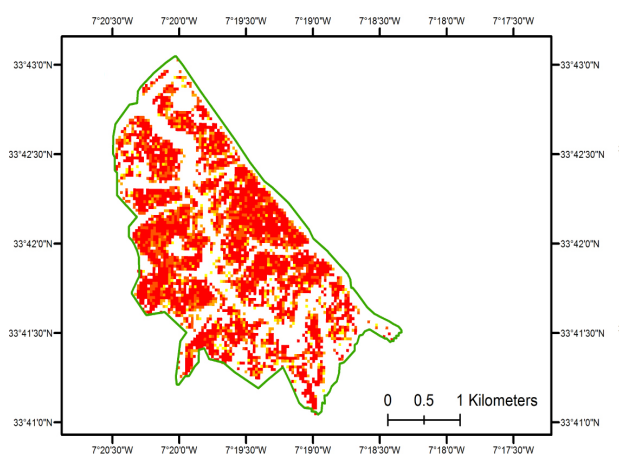

(s)

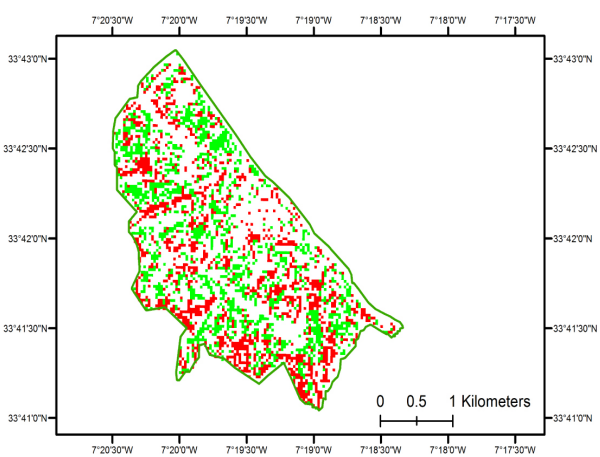

(t)

Figure 2. Indices Vegetation results (a) NDVI 1987; (b) NDVI 2001; (c) NDVI 2015; (d) NDVI Change Detection; (e) SAVI 1987; (f) SAVI 2001; (g) 2015; (h) SAVI C.D; (i) TC Greenness 1987; (j) TC Greenness 2001; (k) TC Greenness 2015; (l) TC Greenness C.D; (m) TC Wetness 1987; (n) TC Wetness 2001; (o) TC Wetness 2015. Subpixel Classification results; (p) TC Wetness C.D; (q) subpiwel C. 1987; (r) subpixel C. 2001; (s) subpixel C. 2015. Change Detection results; (t) Subpixel C.D.

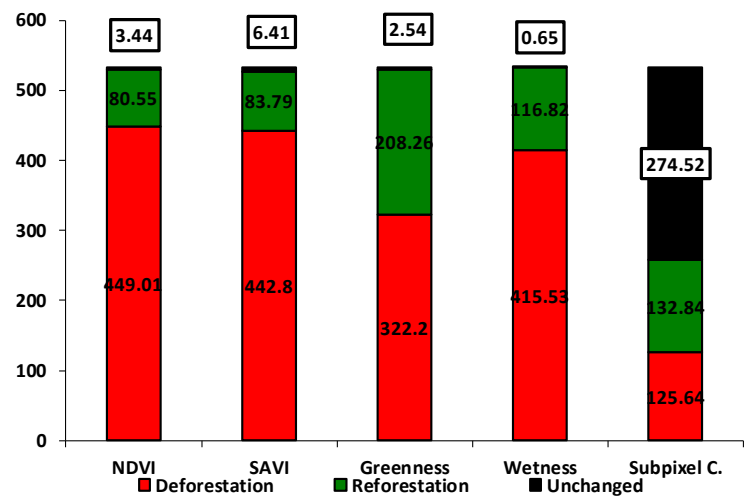

Figure 3. Histogram of change detection area for vegetation indices and subpixel classification (Hectares).

Table 1. Change detection area for vegetation indices and subpixel classification.

\begin{tabular}{cccccc}
\hline Change Detection & NDVI & SAVI & Greenness & Wetness & Subpixel C. \\
\hline Deforestation & 449.01 ha & 442.8 & 322.2 & 415.53 & 125.64 \\
Reforestation & 80.55 ha & 83.79 & 208.26 & 116.82 & 132.84 \\
Unchanged & 3.44 ha & 6.41 & 2.54 & 0.65 & 274.52 \\
\hline
\end{tabular}


accuracy and Kappa accuracy were computed for measuring map accuracy. Overall accuracy was $81.06 \%$ and Kappa accuracy of $76.7 \%$, which seemed to be acceptable.

Different land uses endure different changes [61]. The Detection change was used to estimate and detect transformations and spatial density changes by quantifying the number of density pixels processed [62].

The results of detection Change of Forest Cover in Nfifikh Forest from 1987 to 2015 of NDVI, SAVI, Tasseled Cape Greenness, and Wetness Indices showed a reasonably significant regression of vegetation, with only at most 6 hectares that have not undergone changes for the indices of vegetation and $274.52 \mathrm{hec}$ tares for Subpixel classification.

The change detection in Nfifikh forest between 1987 and 2001 has been calculated, and shows an increased vegetation dynamics of 324.38 hectares, which is $60.86 \%$ of the forest area, and contrariwise the change detection between 2001 and 2015 represents a regression of 464.04 hectares, $87.06 \%$ of the total forest area.

All the change detection maps were overlaid for indices as well as the subpixel classification, and according to Figure 4 and Table 2, the deforested areas are $52.09 \%$ of the total area and only $5.60 \%$ for the reforested areas. It ought to be noted that the forest Nfifikh has experienced a significant decline and particularly by the river and also in the south while within the north there is a small parcels that have not been damaged.

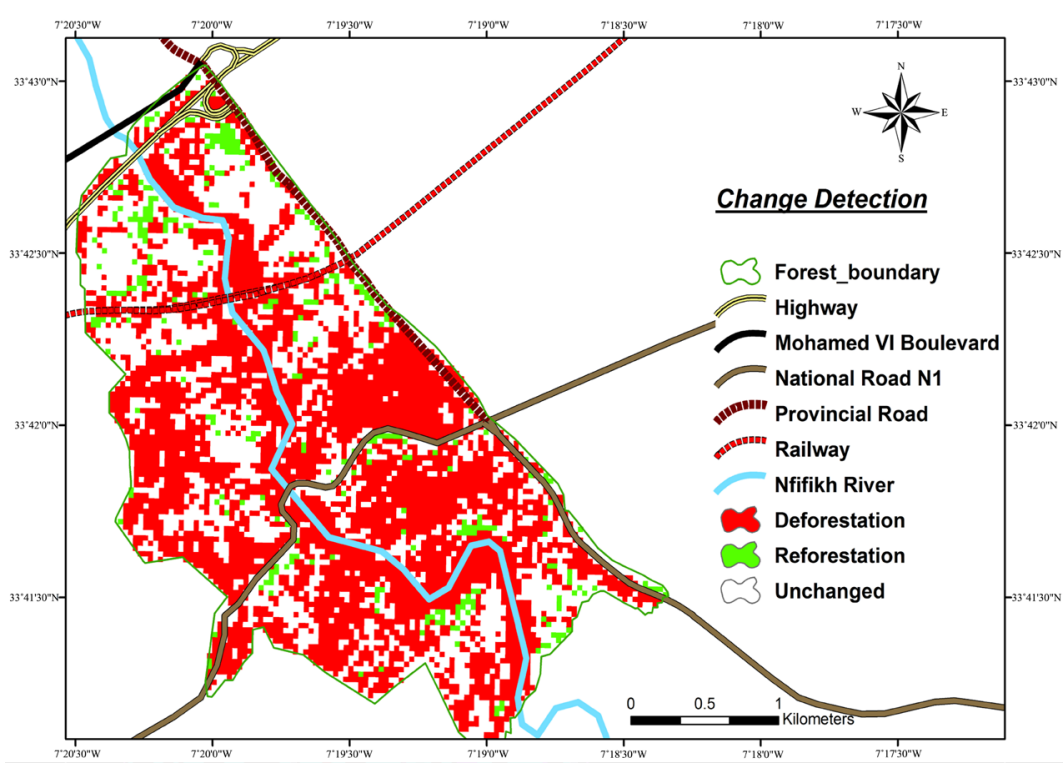

Figure 4. Nfifikh forest cover change detection sum overlay between 1987 and 2015.

Table 2. Change detection area for Nfifikh forest.

\begin{tabular}{ccc}
\hline Change & Area (Hectares) & $\%$ \\
\hline Deforestation & 277.65 & 52.09 \\
Reforestation & 29.88 & 5.6 \\
Unchanged & 225.47 & 42.31 \\
\hline
\end{tabular}


Note that the forest Nfifikh experienced between 2003 and 2010, ten fires whose cause remains unknown, however the damage is negligible 6.13 hectares, also parasite attacks of Pine processionary and Phoracantha semipunctata, although the forestry services reforested an area of 305 hectares during 2001 to 2013, but remains insufficient [43].

Forest regression may be explained by the strong anthropogenic activity, the riparian population and tourists use the forest as a waste dump, especially by the riverside, likewise overgrazing and overexploitation of wood. There are also atmospheric pollution from roads, the highway and the railway that cross the forest.

\section{Conclusions}

The remote sensing is the best tool to detect and measure any changes. This study focused on the assessment and monitoring of Nfifikh forest cover between 1987 and 2015. The combination of vegetation indices with the subpixel classification was useful in estimating the degree of deforestation and assessing forest resources.

The Landsat images allowed a forest state outlook and ability to extract a reforestation between 1987 and 2001 and a remarkable deforestation in 2015. Water and Forests Direction had to intervene and realized plantations to remedy it, but the density is still fairly low.

In conclusion, satellite images are very helpful to measure forest cover. Non forest areas can be easily detected using several approaches and help us in an easy way to reveal the health and density of the forest. Subpixel classification showed us all the changes within the pixel. The forest monitoring is negative. We should necessarily increase density with plantations, foremost to remedy the parasites that attack the trees and more research must be conducted to find out the liable factors.

\section{References}

[1] Aguilar, F.J., Nemmaoui, A., Aguilar, M.A., Chourak, M., Zarhloule, Y. and García Lorca, A.M. (2016) A Quantitative Assessment of Forest Cover Change in the Moulouya River Watershed (Morocco) by the Integration of a Subpixel-Based and Object-Based Analysis of Landsat Data. Forests, 7, 23. https://doi.org/10.3390/f7010023

[2] Martínez, J., Vega-Garcia, C., and Chuvieco, E. (2009) Human-Caused Wildfire Risk Rating for Prevention Planning in Spain. Journal of Environmental Management, 90, 1241-1252. https://doi.org/10.1016/j.jenvman.2008.07.005

[3] Simula, M. (2009) Towards Defining Forest Degradation: Comparative Analysis of Existing Definitions. Forest Resources Assessment Working Paper, 154.

[4] Hansen, M.C., Roy, D.P., Lindquist, E., Adusei, B., Justice, C.O. and Altstatt, A. (2008) A Method for Integrating MODIS and Landsat Data for Systematic Monitoring of Forest Cover and Change in the Congo Basin. Remote Sensing of Environment, 112, 2495-2513. https://doi.org/10.1016/j.rse.2007.11.012

[5] Cuenca, P., Arriagada, R. and Echeverría, C. (2016) How Much Deforestation Do 
Protected Areas Avoid in Tropical Andean Landscapes? Environmental Science \& Policy, 56, 56-66. https://doi.org/10.1016/j.envsci.2015.10.014

[6] Kinoshita, T., Inoue, K., Iwao, K., Kagemoto, H. and Yamagata, Y. (2009) A Spatial Evaluation of Forest Biomass Usage Using GIS. Applied Energy, 86, 1-8. https://doi.org/10.1016/j.apenergy.2008.03.017

[7] Song, X.-P., Huang, C., Sexton, J.O., Channan, S. and Townshend, J.R. (2014) Annual Detection of Forest Cover Loss Using Time Series Satellite Measurements of Percent Tree Cover. Remote Sensing, 6, 8878-8903. https://doi.org/10.3390/rs6098878

[8] Romero-Sanchez, M.E. and Ponce-Hernandez, R. (2017) Assessing and Monitoring Forest Degradation in a Deciduous Tropical Forest in Mexico via Remote Sensing Indicators. Forests, 8, 302. https://doi.org/10.3390/f8090302

[9] Haque, M.I. and Basak, R. (2017) Land Cover Change Detection Using GIS and Remote Sensing Techniques: A Spatio-Temporal Study on Tanguar Haor, Sunamganj, Bangladesh. The Egyptian Journal of Remote Sensing and Space Science, 20, 251-263. https://doi.org/10.1016/j.ejrs.2016.12.003

[10] Villa, P., Lechi, G. and Gomarasca, M.A. (2009) Multivariate Differencing Techniques for Land Cover Change Detection: The Normalized Difference Reflectance Approach. In: Geoscience and Remote Sensing, InTech., 277-301. https://doi.org/10.5772/8312

[11] Margono, B.A., Turubanova, S., Zhuravleva, I., Potapov, P., Tyukavina, A., Baccini, A., et al. (2012) Mapping and Monitoring Deforestation and Forest Degradation in Sumatra (Indonesia) Using Landsat Time Series Data Sets from 1990 to 2010. Environmental Research Letters, 7, Article ID: 034010. https://doi.org/10.1088/1748-9326/7/3/034010

[12] Schultz, M., Clevers, J.G., Carter, S., Verbesselt, J., Avitabile, V., Quang, H.V. and Herold, M. (2016) Performance of Vegetation Indices from Landsat Time Series in Deforestation Monitoring. International Journal of Applied Earth Observation and Geoinformation, 52, 318-327. https://doi.org/10.1016/j.jag.2016.06.020

[13] Morton, D.C., DeFries, R.S., Shimabukuro, Y.E., Anderson, L.O., Arai, E., del Bon Espirito-Santo, F., et al. (2006) Cropland Expansion Changes Deforestation Dynamics in the Southern Brazilian Amazon. Proceedings of the National Academy of Sciences, 103, 14637-14641. https://doi.org/10.1073/pnas.0606377103

[14] Huete, A., Didan, K., Miura, T., Rodriguez, E.P., Gao, X. and Ferreira, L.G. (2002) Overview of the Radiometric and Biophysical Performance of the MODIS Vegetation Indices. Remote Sensing of Environment, 83, 195-213. https://doi.org/10.1016/S0034-4257(02)00096-2

[15] Lyon, J.G., Yuan, D., Lunetta, R.S. and Elvidge, C.D. (1998) A Change Detection Experiment Using Vegetation Indices. Photogrammetric Engineering and Remote Sensing, 64, 143-150.

[16] Ochego, H. (2003) Application of Remote Sensing in Deforestation Monitoring: A Case Study of the Aberdares (Kenya). 2nd FIG Regional Conference, Marrakech, Morocco, 2-5 December 2003, 1-10.

[17] Lea, R., Blodgett, C., Diamond, D. and Schanta, M. (2004) Using the Tasseled Cap Transformation to Identify Change in the Missouri Ozark Forests. Proceedings of the ASPRS Fall Conference Images to Decisions. Remote Sensing Foundations for GIS Applications, 1-12.

[18] Yang, L., Xian, G., Klaver, J.M. and Deal, B. (2003) Urban Land-Cover Change Detection through Sub-Pixel Imperviousness Mapping Using Remotely Sensed Data. 
Photogrammetric Engineering \& Remote Sensing, 69, 1003-1010. https://doi.org/10.14358/PERS.69.9.1003

[19] Wang, T. (2016) Vegetation NDVI Change and Its Relationship with Climate Change and Human Activities in Yulin, Shaanxi Province of China. Journal of Geoscience and Environment Protection, 4, 28-40. https://doi.org/10.4236/gep.2016.410002

[20] Ghebrezgabher, M.G., Yang, T., Yang, X., Wang, X. and Khan, M. (2016) Extracting and Analyzing Forest and Woodland Cover Change in Eritrea Based on Landsat Data Using Supervised Classification. The Egyptian Journal of Remote Sensing and Space Science, 19, 37-47. https://doi.org/10.1016/j.ejrs.2015.09.002

[21] Kumar, P., Rani, M., Pandey, P.C., Majumdar, A. and Nathawat, M.S. (2010) Monitoring of Deforestation and Forest Degradation Using Remote Sensing and GIS: A Case Study of Ranchi in Jharkhand (India). Report and Opinion, 2, 55-67.

[22] Xue, J. and Su, B. (2017) Significant Remote Sensing Vegetation Indices: A Review of Developments and Applications. Journal of Sensors, 2017, Article ID: 1353691. https://doi.org/10.1155/2017/1353691

[23] Nori, W., Elsidding, E.N. and Niemeyer, I. (2008) Detection of Land Cover Changes Using Multi-Temporal Satellite Imagery. The International Archives of the Photogrammetry, Remote Sensing and Spatial Information Sciences, 37, 947-952.

[24] Huete, A.R. (1988) A Soil-Adjusted Vegetation Index (SAVI). Remote Sensing of Environment, 25, 295-309. https://doi.org/10.1016/0034-4257(88)90106-X

[25] Healey, S.P., Cohen, W.B., Zhiqiang, Y. and Krankina, O.N. (2005) Comparison of Tasseled Cap-Based Landsat Data Structures for Use in Forest Disturbance Detection. Remote Sensing of Environment, 97, 301-310. https://doi.org/10.1016/j.rse.2005.05.009

[26] Jin, S. and Sader, S.A. (2005) Comparison of Time Series Tasseled Cap Wetness and the Normalized Difference Moisture Index in Detecting Forest Disturbances. Remote Sensing of Environment, 94, 364-372. https://doi.org/10.1016/j.rse.2004.10.012

[27] Masek, J.G., Huang, C., Wolfe, R., Cohen, W., Hall, F., Kutler, J. and Nelson, P. (2008) North American Forest Disturbance Mapped from a Decadal Landsat Record. Remote Sensing of Environment, 112, 2914-2926. https://doi.org/10.1016/j.rse.2008.02.010

[28] Hais, M., Jonášová, M., Langhammer, J. and Kučera, T. (2009) Comparison of Two Types of Forest Disturbance Using Multitemporal Landsat TM/ETM+ Imagery and Field Vegetation Data. Remote Sensing of Environment, 113, 835-845. https://doi.org/10.1016/j.rse.2008.12.012

[29] Rozario, P.F., Oduor, P.G., Kotchman, L. and Kangas, M. (2017) Uncertainty Analysis of Spatial Autocorrelation of Land-Use and Land-Cover Data within Pipestem Creek in North Dakota. Journal of Geoscience and Environment Protection, 5, 71-88. https://doi.org/10.4236/gep.2017.58008

[30] Ruhoff, A.L., Castro, N.M.R. and Risso, A. (2011) Numerical Modelling of the Topographic Wetness Index: An Analysis at Different Scales. International Journal of Geosciences, 2, 476-483. https://doi.org/10.4236/ijg.2011.24050

[31] Baumann, M., Ozdogan, M., Wolter, P.T., Krylov, A., Vladimirova, N. and Radeloff, V.C. (2014) Landsat Remote Sensing of Forest Windfall Disturbance. Remote Sensing of Environment, 143, 171-179. https://doi.org/10.1016/j.rse.2013.12.020

[32] Huguenin, R.L., Karaska, M.A., Van Blaricom, D. and Jensen, J.R. (1997) Subpixel 
Classification of Bald Cypress and Tupelo Gum Trees in Thematic Mapper Imagery. Photogrammetric Engineering and Remote Sensing, 63, 717-725.

[33] Verbeiren, S., Eerens, H., Piccard, I., Bauwens, I. and Van Orshoven, J. (2008) Sub-Pixel Classification of SPOT-VEGETATION Time Series for the Assessment of Regional Crop Areas in Belgium. International Journal of Applied Earth Observation and Geoinformation, 10, 486-497. https://doi.org/10.1016/j.jag.2006.12.003

[34] Hayes, D.J. and Sader, S.A. (2001) Comparison of Change-Detection Techniques for Monitoring Tropical Forest Clearing and Vegetation Regrowth in a Time Series. Photogrammetric Engineering and Remote Sensing, 67, 1067-1075.

[35] Afify, H.A. (2011) Evaluation of Change Detection Techniques for Monitoring Land-Cover Changes: A Case Study in New Burg El-Arab Area. Alexandria Engineering Journal, 50, 187-195. https://doi.org/10.1016/j.aej.2011.06.001

[36] Nordberg, M.L. and Evertson, J. (2005) Vegetation Index Differencing and Linear Regression for Change Detection in a Swedish Mountain Range Using Landsat TM $^{\circledR}$ and ETM $+{ }^{\circledR}$ Imagery. Land Degradation \& Development, 16, 139-149.

[37] Sahebjalal, E. and Dashtekian, K. (2013) Analysis of Land Use-Land Covers Changes Using Normalized Difference Vegetation Index (NDVI) Differencing and Classification Methods. African Journal of Agricultural Research, 8, 4614-4622.

[38] Mas, J.F. (1999) Monitoring Land-Cover Changes: A Comparison of Change Detection Techniques. International Journal of Remote Sensing, 20, 139-152. https://doi.org/10.1080/014311699213659

[39] Ashutosh, S. (2012) Monitoring Forests: A New Paradigm of Remote Sensing \& GIS Based Change Detection. Journal of Geographic Information System, 4, 470-478. https://doi.org/10.4236/jgis.2012.45051

[40] Onojeghuo, A.O. and Onojeghuo, A.R. (2015) Dynamics of Forest Landscape Transition across Protected Areas in the Niger Delta from 1986 to 2014. Journal of Geoscience and Environment Protection, 3, Article ID: 59329. https://doi.org/10.4236/gep.2015.37001

[41] Adedeji, O.H. and Adeofun, C.O. (2014) Spatial Pattern of Land Cover Change Using Remotely Sensed Imagery and GIS: A Case Study of Omo-Shasha-Oluwa Forest Reserve, SW Nigeria (1986-2002). Journal of Geographic Information System, 6, 375-385. https://doi.org/10.4236/jgis.2014.64033

[42] Torahi, A.A. and Rai, S.C. (2011) Land Cover Classification and Forest Change Analysis, Using Satellite Imagery-A Case Study in Dehdez Area of Zagros Mountain in Iran. Journal of Geographic Information System, 3, 1-11. https://doi.org/10.4236/jgis.2011.31001

[43] Regional Directorate of Forestry Center (2012) Study of Recreational and Forest Management of Nfifikh Forest. Casablanca.

[44] High Commission for Water and Forests and the Fight against Desertification. (2005) Integrated Rural Development Project for Forest and Pre-Forest Areas: Environmental Assessment (Final Report).

[45] Khatami, A., Ponche, J.L., Jabry, E. and Mirabel, P. (1998) The Air Quality Management of the Region of Great Casablanca (Morocco). Part 1: Atmospheric Emission Inventory for the Year 1992. Science of the Total Environment, 209, 201-216. https://doi.org/10.1016/S0048-9697(98)80111-3

[46] Hoja, D., Schneider, M., Müller, R., Lehner, M. and Reinartz, P. (2008) Comparison of Orthorectification Methods Suitable for Rapid Mapping Using Direct Georeferencing and RPC for Optical Satellite Data. The International Archives of the Pho- 
togrammetry, Remote Sensing and Spatial Information Sciences, 37, 1617-1624.

[47] Huete, A.R., Liu, H.Q., Batchily, K. and Van Leeuwen, W.J.D.A. (1997) A Comparison of Vegetation Indices over a Global Set of TM Images for EOS-MODIS. Remote Sensing of Environment, 59, 440-451.

https://doi.org/10.1016/S0034-4257(96)00112-5

[48] Price, J.C. (1987) Calibration of Satellite Radiometers and the Comparison of Vegetation Indices. Remote Sensing of Environment, 21, 15-27. https://doi.org/10.1016/0034-4257(87)90003-4

[49] Sall, B.R. (2013) Retrospective Analysis of Two Northern California Wild-Land Fires via Lands at Five Satellite Imagery and Normalized Difference Vegetation Index (NDVI). Open Journal of Ecology, 3, 311-323. https://doi.org/10.4236/oje.2013.34036

[50] Zhang, X., Lu, X. and Wang, X. (2015) Spatial-Temporal NDVI Variation of Different Alpine Grassland Classes and Groups in Northern Tibet from 2000 to 2013. Mountain Research and Development, 35, 254-263. https://doi.org/10.1659/MRD-JOURNAL-D-14-00110.1

[51] Aguilar, C., Zinnert, J.C., Polo, M.J. and Young, D.R. (2012) NDVI as an Indicator for Changes in Water Availability to Woody Vegetation. Ecological Indicators, 23, 290-300. https://doi.org/10.1016/j.ecolind.2012.04.008

[52] Rondeaux, G., Steven, M. and Baret, F. (1996) Optimization of Soil-Adjusted Vegetation Indices. Remote Sensing of Environment, 55, 95-107. https://doi.org/10.1016/0034-4257(95)00186-7

[53] Crist, E.P. and Cicone, R.C. (1984) Application of the Tasseled Cap Concept to Simulated Thematic Mapper Data. Photogrammetric Engineering \& Remote Sensing, 50, 343-352.

[54] Du, P., Liu, S., Liu, P., Tan, K. and Cheng, L. (2014) Sub-Pixel Change Detection for Urban Land-Cover Analysis via Multi-Temporal Remote Sensing Images. Geo-Spatial Information Science, 17, 26-38. https://doi.org/10.1080/10095020.2014.889268

[55] Flanagan, M. and Civco, D.L. (2001) Subpixel Impervious Surface Mapping. Proceedings of the 2001 ASPRS Annual Convention, St. Louis, MO, April 2001, 1-13.

[56] Hegazy, I.R. and Kaloop, M.R. (2015) Monitoring Urban Growth and Land Use Change Detection with GIS and Remote Sensing Techniques in Daqahlia Governorate Egypt. International Journal of Sustainable Built Environment, 4, 117-124. https://doi.org/10.1016/j.ijsbe.2015.02.005

[57] Veettil, B.K. (2012) A Comparative Study of Urban Change Detection Techniques Using High Spatial Resolution Quickbird and WorldView-2 Images. IV Simpósio Brasileiro de Ciências Geodésicas e Tecnologias da Geoinformação, CTP, Recife, 6-9 June 2012, 1-8.

[58] Magesh, N.S., Chandrasekar, N. and Soundranayagam, J.P. (2012) Delineation of Groundwater Potential Zones in Theni District, Tamil Nadu, Using Remote Sensing, GIS and MIF Techniques. Geoscience Frontiers, 3, 189-196. https://doi.org/10.1016/j.gsf.2011.10.007

[59] Valente, R.D.O.A. and Vettorazzi, C.A. (2008) Definition of Priority Areas for Forest Conservation through the Ordered Weighted Averaging Method. Forest Ecology and Management, 256, 1408-1417. https://doi.org/10.1016/j.foreco.2008.07.006

[60] Nagarajan, M. and Singh, S. (2009) Assessment of Groundwater Potential Zones Using GIS Technique. Journal of the Indian Society of Remote Sensing, 37, 69-77. https://doi.org/10.1007/s12524-009-0012-Z 
[61] Ranjan, A.K., Anand, A., Vallisree, S. and Singh, R.K. (2016) LU/LC Change Detection and Forest Degradation Analysis in Dalma Wildlife Sanctuary Using 3S Technology: A Case Study in Jamshedpur-India. AIMS Geosciences, 2, 273-285.

[62] El-Aziz, A.O.A. (2013) Monitoring and Change Detection along the Eastern Side of Qena Bend, Nile Valley, Egypt Using GIS and Remote Sensing. Advances in Remote Sensing, 2, 276-281. https://doi.org/10.4236/ars.2013.23030 